\title{
Agroindustrial performance and phenotypic parameters evaluation of sugarcane varieties in different crop seasons
}

\section{Desempenho agroindustrial e avaliação de parâmetros fenotípicos em variedades de cana-de-açúcar em diferentes colheitas}

\author{
Maurício F. Lopes ${ }^{1}$, Fernanda M. R. Castro ${ }^{1^{\star}}$, Adriano T. Bruzi ${ }^{1}$, Luíz Antônio de B. Andrade ${ }^{1}$, \\ José Airton R. Nunes ${ }^{2}$ and Luciane R. Sales ${ }^{3}$ \\ ${ }^{1}$ Department of Agriculture, Lavras Federal University (UFLA), Lavras/MG, Brazil \\ 2 Department of Biology, Lavras Federal University (UFLA), Lavras/MG, Brazil \\ ${ }^{3}$ Department of Soil Science, Lavras Federal University (UFLA), Lavras/MG, Brazil \\ ( ${ }^{E}$-mail: fefernandacastro@hotmail.com) \\ http://dx.doi.org/10.19084/RCA17310
}

Received/recebido: 2017.11.30

Accepted/aceite: 2018.03 .20

\begin{abstract}
A B S T R A C T
Sugarcane can be cultivated as raw material for craft cachaça production and forage for animal feed, but usually a good technological input is not used, because varieties for sugar and ethanol production are planted. The aim of this study was to evaluate the agroindustrial performance and the estimation of phenotypic parameters of sugarcane varieties of the first and second crop seasons. The experimental design was a triple lattice $4 \times 4$, being assessed sixteen varieties of three different institutions. Agronomic and technological characters with agroindustrial importance were evaluated. There was a significant difference between the varieties and the crop seasons for the traits evaluated in the joint analysis. The phenotypic parameters analysis contributed to the understanding of the traits performance throughout two crop seasons. Varieties do not present a similar behavior, however, they have regularity in the performance, over time, for most agronomic and industrial characters evaluated. Phenotypic characteristics POL and TRS, show good reliability in predicting the genotypic value for these variables. The high number of measurements required for the TSH, Purity and SM characters make it difficult to select potential varieties. Phenotypic correlation evaluated in two harvests is not sufficient to carry out the recommendation of varieties.
\end{abstract}

Keywords: Saccharum spp., varietal competition, interaction varieties x crop seasons.

\section{R E S U M O}

A cana-de-açúcar pode ser cultivada como matéria-prima para a produção de cachaça artesanal e forragem para alimentação animal, porém normalmente não se utiliza um bom aporte tecnológico, pois são plantadas variedades usadas para produção de açúcar e álcool. Este trabalho teve como objetivo avaliar o desempenho agroindustrial e a estimativa de parâmetros fenotípicos em variedades de cana-de-açúcar avaliadas em duas safras. O delineamento experimental utilizado foi o látice triplo 4 × 4, sendo avaliadas dezasseis variedades de três diferentes instituições. Foram avaliados caracteres agronómicos e tecnológicos com importância agroindustrial. Houve diferença significativa entre as variedades e as safras para os caracteres avaliados na análise conjunta. A análise dos parâmetros fenotípicos contribuiu para o entendimento do desempenho dos caracteres ao longo das duas safras. As variedades possuem comportamento dessemelhante, porém, apresentam regularidade no desempenho, ao longo do tempo, para a maioria dos caracteres agronómicos e industriais avaliados. As características fenotípicas POL e ATR, denotam boa confiabilidade em prever o valor genotípico para estas variáveis. O alto número de medições necessárias para os caracteres TCH, PUREZA e MMC, dificultam a seleção de variedades potenciais. A correlação fenotípica avaliada em duas safras não é suficiente para realizar a recomendação de variedades.

Palavras-chave: Saccharum spp., competição varietal, interação variedades x colheitas. 


\section{INTRODUCTION}

Sugarcane plays an important role because it is the raw material for the production of artisanal cachaça and forage, therefore the adapted varieties knowledge to specific regions, considering local edaphoclimatic conditions, is very important to the culture productive chain.

The definition of the best varieties for a given producing region should be based on a set of agroindustrial interest traits, as well as on the estimation of phenotypic parameters of the genotypes under study (Ferreira et al., 2005; Fernandes Júnior et al., 2017). In this sense, authors such as Brito et al. (2013), Ferreira et al. (2005), Ftwi et al. (2017) and Souza et al. (2012) conducted studies whose objective was to identify the most adapted varieties to specific crop regions in different agricultural crop seasons.

For Souza et al. (2012) the understanding of the dynamics of the sugarcane agroindustrial traits, during the different cultivation years, can contribute to the improvement of cultural practices, as well as in the best exploitation of the varieties that are more productive and adapted to the different production environments. The analysis of these traits allowed knowing the functional and structural differences between varieties, making possible to select them to meet the cultivation objectives in a determined producing region.

In addition to the agroindustrial performance study, the estimation of sugarcane phenotypic parameters, contributes to the understanding of crop performance throughout the different cultivation cycles (Fernandes Júnior et al., 2017). Cavalcante et al. (2012) consider important the phenotypic parameters study to provide information for the implementation and conduction of breeding programs, reducing costs for the proper choice of varieties. Among these parameters deserve to be highlighted the repeatability coefficient, determination coefficient, phenotypic correlation of the combination of the different years and minimum number of measurements necessary to predict the value of the genotype.

The analysis of the agroindustrial performance and the estimation of the phenotypic parameters in the varieties will provide an understanding of the varieties performance in the different harvests, subsidizing a later recommendation of the most indicated to the region of production. So, this study aimed to evaluate the agroindustrial performance and the phenotypic parameters evaluation of sugarcane varieties in the first and second crop seasons in Lavras/MG.

\section{MATERIAL AND METHODS}

The experiment was carried out in the city of Lavras/MG, at $21^{\circ} 14^{\prime}$ South latitude, $45^{\circ} 00^{\prime}$ West longitude and altitude of $920 \mathrm{~m}$ from sea level. Experimental area soil was classified as typical dystroferric Red Latosol, with very clayey texture (Lvdf).

The area where the experiment was installed had been already cultivated with sugarcane for more than five years. The soil was prepared in the conventional cultivation system, with plowing followed by harrowing and the grooves opening was done by mechanized traction. The liming was done in the planting groove at the dosage of $2 \mathrm{t} \mathrm{ha}^{-1}$. Base fertilization in the planting groove was done with $650 \mathrm{~kg}$ ha-1 $^{-1}$ of the NPK 8-28-16 formulation, according to the soil chemical analysis (Table 1). In the cover fertilization, $500 \mathrm{~kg} \mathrm{ha}^{-1}$ and $250 \mathrm{~kg} \mathrm{ha}^{-1}$ of urea were applied at 30 and 60 days after planting, respectively, and in the second

Table 1 - Chemical analysis of the experimental area at 20 and $40 \mathrm{~cm}$ of the soil profile depth

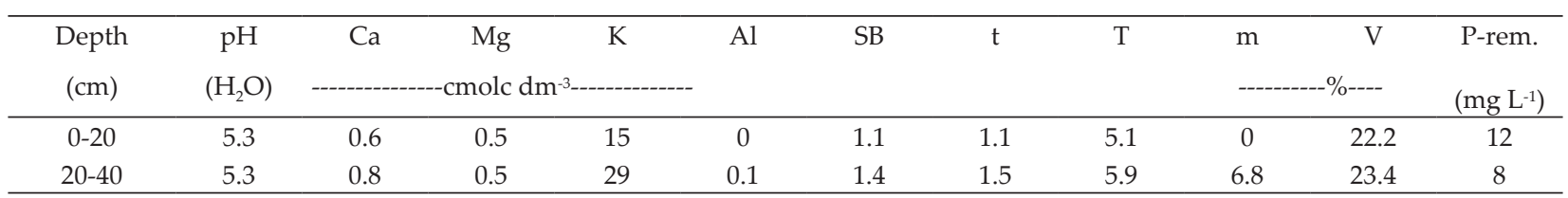

$\mathrm{pH}$ in water; calcium - Ca; magnesium - Mg; potassium - K; aluminium - Al; sum of bases - SB; effective cation exchange capacity - t; cation exchange capacity on pH 7 - T; base saturation - V; saturation by aluminum - $\mathrm{m}$; remaining phosphorus - P-rem 
crop season was applied $400 \mathrm{~kg} \mathrm{ha}^{-1}$ of the NPK 20-05-20 formulation soon after harvest.

Sixteen sugarcane varieties were assessed from three different institutions: RIDESA (RB925211, RB925345, RB855453 and RB867515); CTC (CTC9, CTC2, CTC7, CTC14, CTC15, CTC16, CTC8 and CTC1) and COOPERSUCAR (SP891115, SP801842, SP813250 and SP842025).

Experimental plots consisted of three lines of $5 \mathrm{~m}$, spaced $1.30 \mathrm{~m}$ apart, with an effective area of $19.5 \mathrm{~m}^{2}$. The planting was carried out in November 2011, and the cultural treatments were done according to sugarcane farmers' recommendation in Lavras region. Sugarcane harvest was in November 2012 (crop season 2011/2012) and the first ratoon in November 2013 (crop season 2012/2013). During the experiment conduction, occurred 1.598 and $1.252 \mathrm{~mm}$ of precipitation for the first and second crop seasons, respectively, according to Figure 1.

The agronomic traits evaluated in each experimental plot were: a) stalks average number per linear meter (SN), obtained by the count of total stalks of the three lines and posterior division of the result obtained by the number of linear meters; b) stalk average diameter (SD), obtained in $\mathrm{mm}$, taking the diameter of nine plants at random, three of the central region of each row; c) stalk average height $(\mathrm{SH})$, measured in centimeters from the soil level to the insertion of leaf, measuring the same three plants used to determine the stalk average diameter; d) stalks average mass (SM), obtained through the mean value of the weight of ten stalks with no apex and leaves, collected in sequence on the center line; e) tons of stalks per hectare (TSH), harvesting and weighing all plants from the three lines, which had the apex and leaves removed, extrapolating the obtained value for tons of sugarcane per hectare..

For the industrial traits analysis the same ten stalks of the average mass calculation were used. The assessed traits were: a) saccharimetric reading of sugarcane juice (Pol\% cane); b) apparent sugarcane juice purity (Purity\% sugarcane juice); c) total recoverable sugar (TRS); d) total soluble solids

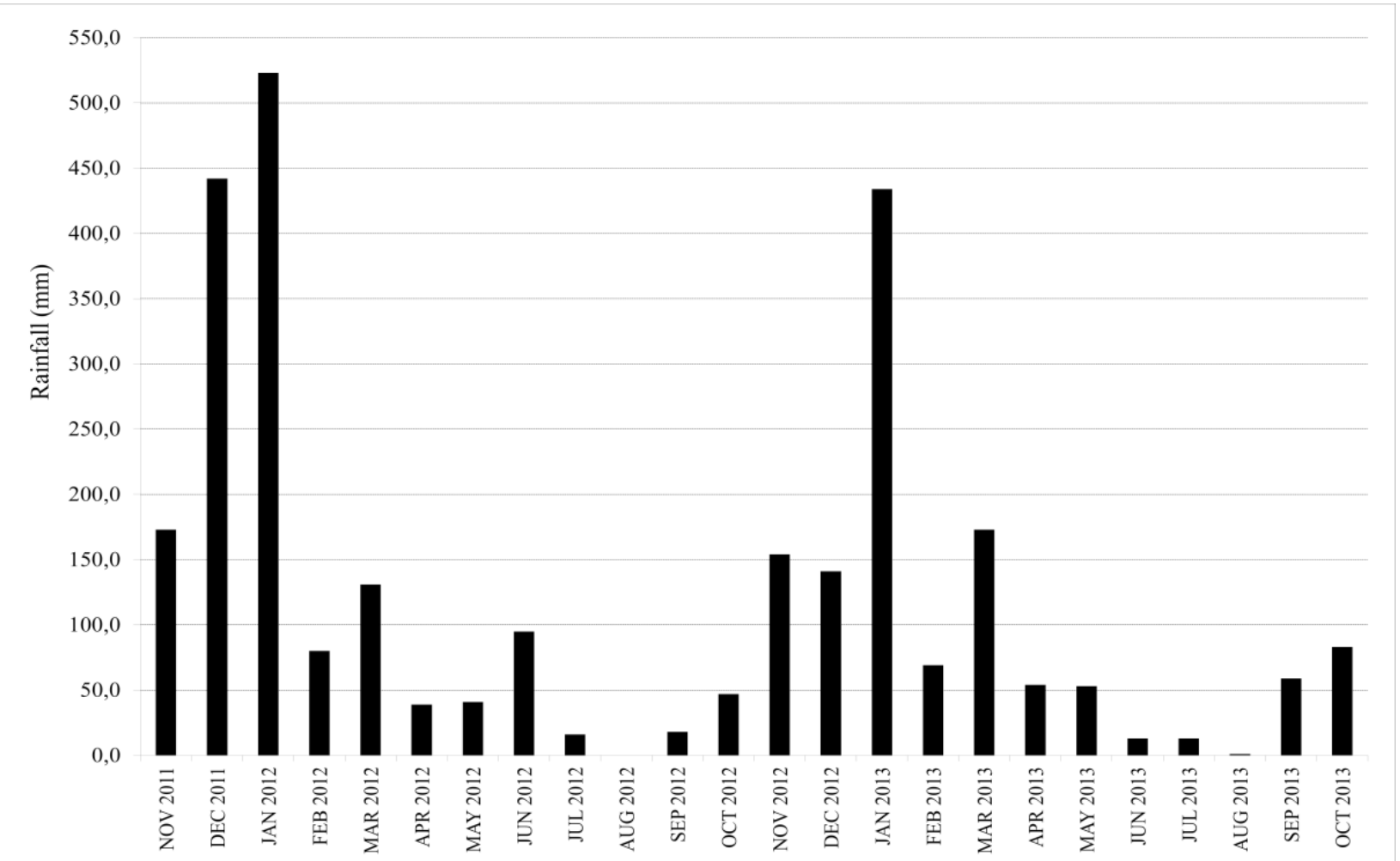

Figure 1 - Monthly variation of rainfall referred to the months of the years 2011, 2012 and 2013 in Lavras/MG. 
content in the sugarcane juice (TSS - ${ }^{\circ}$ Brix); e) cane fiber (Fiber\% cane); f) tons of Pol per hectare (TPH).

The experimental design was the $4 \times 4$ triple lattice. For the individual analysis of the data, through analysis of variance, it was used the statistical model adapted from Ramalho et al. (2012) for each crop season: $Y_{i l(j)}=\mu+r_{j}+t_{i}+(b / r)_{l(j)}+e_{i l(j)}$, where $Y_{i l(j)}$ is the observation of the plot that received the $i$ variety in the $l$ block of the $j$ repetition, $\mu$ is an inherent constant to all observations, $r_{j}$ is the fixed effect of the $j$ repetition, $t_{i}$ is the fixed effect of the $i$ variety, $(b / r)_{l(i)}$ is the effect of the incomplete block $l$ within the $j$ repetition, being $b / r_{l(j)} \sim \mathrm{N}\left(0, \sigma_{b / r}^{2}\right), \sigma_{b / r}^{2}$ is the variance associated to the random effect of the block/repetition, $e_{i l(j)}$ is the error associated to the observation $y_{i l(j)}$, being $e_{i l(j)} \sim \mathrm{N}\left(0, \sigma_{e}^{2}\right)$ and $\sigma_{e}^{2}$ is the variance associated to the random effect of the error.

For the joint analysis of the data, using analysis of variance, it was used the statistical model adapted from Ramalho et al. (2012) for each crop season: $Y_{i p l(j)}=\mu+a_{p}+t_{i}+r_{j}+(b / r)_{l(j)}+(t b / r)_{i l(j)}+a b / r_{p l(j)}+(t a)_{i p}+$ $e_{i p l(j)}$, where $Y_{i p l(j)}$ is the observation of the plot that received the $i$ variety in the $l$ block of the $j$ repetition in the $p$ crop season, $\mu$ is an inherent constant to all observations, $a_{p}$ is the fixed effect of $p$ crop season, $t_{i}$ is the fixed effect of the $i$ variety, $r_{j}$ is the fixed effect of the $j$ repetition, $(b / r)_{l(j)}$ is the random effect of the incomplete block $l$ within the $j$ repetition, being $b / r_{l(j)} \sim \mathrm{N}\left(0, \sigma_{b / r}^{2}\right), \sigma_{b / r}^{2}$ is the variance associated to the random effect of the block/repetition, $(t b / r)_{i l(j)}$ is the effect of the interaction between the variety $i$ and the block $l$ within the $j$ repetition, $a b / r_{p l(j)}$ is the effect of the incomplete block $l$ within the $j$ repetition of the $p$ crop season, $(t a)_{i p}=$ effect of the interaction between variety $i$ within the $p$ crop season, $e_{i p l(j)}$ is the random error associated to the $y_{i l(j)(p)}$ observation, being $e_{i p l(j)} \sim \mathrm{N}\left(0, \sigma_{e}^{2}\right)$ and $\sigma_{e}^{2}$ is the variance associated to the random effect of the error.

From the performed analysis, the following phenotypic parameters were estimated according to Cruz et al. (2004):

(1) selective accuracy:

$\mathrm{SA}=\sqrt{1-1 / F c}$, being $F_{C}=\mathrm{F}$-value test calculated of the genotype;
(2) repeatability coefficient:

$$
r=\frac{(Q M G-Q M R)}{[Q M G+((n-1) Q M R)]}
$$

being MSG = mean square of genotype, $\mathrm{MSE}=$ mean square of error and $n=$ number of crop seasons;

(3) determination coefficient:

$R^{2}=\frac{(n r)}{[1+(r(n-1))]} ;$

(4) minimum number of crop seasons needed to predict the true value of the genotype with $95 \%$ confidence:

$$
n_{0}=\frac{[0,95(1-r)]}{[r(1-0,95)]}
$$

(5) mixed phenotypic correlation coefficient of the combination of two harvests:

$r_{\mathrm{x} 1 \times 2}=\frac{\operatorname{Cov}_{\mathrm{Fx1}} \operatorname{Cov}_{\mathrm{Fx} 2}}{\sqrt{V_{\mathrm{F} \times 1} V_{\mathrm{F} \times 2}}}$.

This parameter was calculated from the linear relationship between the same trait in the two different crop seasons, where: $\operatorname{Cov}_{F x 1}$ estimation of phenotypic covariance between trait $x$ crop season 1; $\operatorname{Cov}_{F x 2}=$ estimation of phenotypic covariance between trait $x$ crop season 2; $V_{F x 1}=$ estimation of phenotypic variance between trait $x$ crop season $1 ; V_{F x 2}$ estimation of phenotypic variance between trait $x$ crop season 2 .

Variance analysis was carried out by the statistical-computational system $\mathrm{SAS}^{\circledR}$ at the $5 \%$ probability level through the procedure for the analysis of linear models PROC MIXED (procedure for mixed linear models), Type 3; groupings of means and phenotypic correlation were performed by $\mathrm{R}^{\circledR}$ Statistical Software.

When statistical significance was verified, at the $5 \%$ probability level, the means of the 16 varieties were grouped in the joint analysis by the procedure proposed by Scott and Knott (1974), performed by $\mathrm{R}^{\circledR}$ statistical software. 


\section{RESULTS AND DISCUSSION}

Significant differences were identified among the varieties for all eleven traits assessed in the joint variance analysis (Table 2).

According to Ferreira et al. (2005), Ftwi et al. (2017) and Nascimento Filho et al. (2009) the statistical difference for the varieties denotes the possibility of superior genotypes identification and the selection of the best ones due to the genetic variation between them.

For the crop season factor, there was a significant difference in all evaluated traits, except for the Purity (Table 2). The highest values of mean squares for crop seasons, except for stalk average height, in relation to the mean squares of the cultivar and the interaction cultivars $x$ crop seasons, indicated that there was a great difference between the agricultural crop seasons for the agroindustrial productive potential.

Cargnelutti Filho et al. (2012) verified that there may be an erroneous inference when it is considered only the estimate of one agricultural year for sugarcane varieties recommendation. According to Ramalho et al. (2012) this is due to the fact that semi-perennial plants such as sugarcane are submitted to different environmental conditions during the agricultural years, such as temperature, precipitation, among others, which leads to a strong genotypes $x$ environments interaction.

Selective accuracy had high values in the joint analysis, denoting a good experimental precision according to the classification proposed by Resende and Duarte (2007) (Table 2). For Cargnelutti Filho et al. (2012) the parameters selective accuracy and F test for genotype, of the analysis of variance, are appropriate to evaluate the experimental precision, when assessing the competition between sugarcane varieties.

A significant difference was detected by the $\mathrm{F}$ test for the interaction of varieties $\mathrm{x}$ crop seasons for the assessed traits, except for stalk diameter, ${ }^{\circ}$ Brix, Fiber and Purity (Table 2). The authors Cavalcante et al. (2012), Jackson (2005) and Ftwi et al. (2017) consider that the significant effect of the genotypes $x$ crop seasons interaction indicates a high heterogeneity of environmental conditions, resulting

Table 2 - Analysis of variance of the traits stalk average height (SH) in $\mathrm{cm}$, stalk average diameter (SD) in mm, stalks average mass (SM) in $\mathrm{kg}$ colmo-1, stalks average number per linear meter (SN), tons of stalks per hectare (TSH), total recoverable sugar (TRS), Brix\% sugarcane juice, Fiber\% cane, Pol\% cane, Purity\% sugarcane juice and tons of Pol per hectare (TPH) of 16 varieties of sugarcane assessed in the crop seasons 2011/2012 and 2012/2013

\begin{tabular}{|c|c|c|c|c|c|c|c|}
\hline \multirow{4}{*}{ variation source } & \multicolumn{7}{|c|}{ mean square } \\
\hline & \multirow{3}{*}{ FD } & SH & SD & SM & \multirow{3}{*}{ SN } & \multicolumn{2}{|c|}{ TSH } \\
\hline & & & & & & & \\
\hline & & (cm) & $(\mathrm{mm})$ & $(\mathrm{kg})$ & & \multicolumn{2}{|c|}{$\left(t h^{-1}\right)$} \\
\hline variety $(\mathrm{V})$ & 15 & $0.14^{* *}$ & $17.0^{* *}$ & $0.07^{* *}$ & $17.06^{* *}$ & \multicolumn{2}{|c|}{$809.0^{* *}$} \\
\hline crop season (CS) & 1 & $0.02^{* *}$ & $105.0^{* *}$ & $2.47^{* *}$ & $1,006.0^{* *}$ & \multicolumn{2}{|c|}{$10,726.0^{* *}$} \\
\hline $\mathrm{V} \times \mathrm{CS}$ & 15 & $0.07^{* *}$ & $3.17^{\mathrm{ns}}$ & $0.09^{* *}$ & $8.14^{* *}$ & \multicolumn{2}{|c|}{$506.7^{* *}$} \\
\hline Error & 42 & 0.013 & 1.81 & 0.02 & 3.09 & \multicolumn{2}{|c|}{140.64} \\
\hline overall average & & 1.99 & 27.02 & 0.848 & 11.61 & \multicolumn{2}{|c|}{57.39} \\
\hline selective accuracy & & 0.95 & 0.94 & 0.85 & 0.9 & \multicolumn{2}{|c|}{0.91} \\
\hline \multirow{3}{*}{ variation source } & \multicolumn{7}{|c|}{ mean square } \\
\hline & \multirow{2}{*}{ FD } & \multirow{2}{*}{ TRS } & Brix & Fiber & Pol & Purity & TPH \\
\hline & & & $(\%)$ & $(\%)$ & $(\%)$ & $(\%)$ & $\left(\mathrm{t} \mathrm{ha}^{-1}\right)$ \\
\hline variety & 15 & $294.0^{* *}$ & $2.96^{* *}$ & $2.8^{* *}$ & $3.4^{* *}$ & $4.07^{* *}$ & $25.8^{* *}$ \\
\hline crop season & 1 & $803.0^{* *}$ & $18.7^{* *}$ & $5.8^{* *}$ & $9.3^{* *}$ & $4.90^{\mathrm{ns}}$ & $244.0^{* *}$ \\
\hline $\mathrm{V} \times \mathrm{CS}$ & 15 & $55.2^{*}$ & $0.52^{\mathrm{ns}}$ & $0.5^{\mathrm{ns}}$ & $0.6^{* *}$ & $0.95^{\mathrm{ns}}$ & $15.4^{* *}$ \\
\hline error & 42 & 23.76 & 0.35 & 0.286 & 0.27 & 0.61 & 4.16 \\
\hline overall average & & 165.83 & 21.99 & 13.45 & 17.08 & 94.01 & 9.81 \\
\hline selective accuracy & & 0.96 & 0.94 & 0.95 & 0.96 & 0.92 & 0.92 \\
\hline
\end{tabular}

FD - Freedom degree; ** - significant at $1 \%$ probability $(p<0.01)$; * significant at $5 \%$ probability $(0.01 \leq p \leq 0.05)$; ${ }^{\text {ns }}$ - not significant $(p>0.05)$ by the $F$ test. 
in the occurrence of favorable and unfavorable periods between the years, due to edaphic and climatic variables. Considering the climatic variable precipitation, there was a difference between the accumulated in the different crop seasons, once that at the second year the precipitation was $22 \%$ lower compared to the first agricultural year (Figure 1). As a significant difference was detected in the interaction between varieties and crop seasons for most of the evaluated traits, the unfolding of varieties and harvests was carried out (Tables 3 and 4).

In the 2011/2012 crop season there was a statistical difference between the varieties for all assessed traits, except for NC (Tables 3 and 4). For Brito et al. (2013) the number of stalks varies widely among varieties, but the low experimental precision, obtained for this trait in the first crop season, when the value of the selective accuracy was only 0.65 , a value considered moderate according to the classification proposed by Rezende and Duarte (2007), it was impossible to find significant differences in this experiment.

In relation to the crop season of 2012/2013, there were significant differences between the varieties for all the assessed traits (Tables 3 and 4). A similar result was obtained by Ftwi et al. (2017) studying sugarcane industrial traits, when the authors obtained significant differences for most of the variables evaluated in the first harvests.

For the stalk height trait, all varieties were highest in the second crop season (Table 3). Candido et al. (2009) point out that in order to have a good growth of the varieties it is necessary some time for the roots to grow in the soil, which according to the authors does not occur in the first year of cultivation, unless when the sugarcane is cultivated in one and a half year system, that was not the case in the present study.

In Table 3, it was possible to observe that the stalk average mass was 0.69 and $1.01 \mathrm{~kg}$, respectively, for the first and second crop season. In the first harvest, two large groups were formed, while in the second harvest three groups of averages were formed, and the varieties that presented the best performance for this character were CTC9, СTC2, RB867515 and CTC1.
In relation to the stalks number per linear meter, for Silva et al. (2008) the sugarcane development is positively related to a greater tillering, which results in higher productivity. However, this did not occur in the present study, because not all cultivars that formed the group with the highest value for stalks average number per linear meter in the two crop seasons were in the group with the highest value for tons of stalks per hectare (Table 3). Silva et al. (2007) consider that the number of stalks has a high genetic control, however this did not occur in the present study, once this trait was very influenced by the different cultivation environments, when in the first crop season the average for this trait was only 8.37 stalks per meter, while in the second it was 14.85 stalks per meter (Table 3).

Jackson (2005) highlights that the trait TSH is one of the main traits to be considered and should always be a focus in sugarcane breeding programs. Only two groups were formed with the means of the first crop season, while in the second, three groups were identified (Table 3). For Ftwi et al. (2017), this trait is very influenced by the different crop seasons, which can be proven in the present work, once there was a better average performance among the varieties for this trait in the second harvest, except for variety SP891115, which had phytosanitary problems in the 2012/2013 crop season. This phenotypic variability provides favorable results for the indication of varieties with good industrial characteristics in the cultivation region.

For the industrial traits TRS and POL, there was great variation amplitude, with the formation of three groups of means in the two different assessed harvests (Table 4). This phenotypic variability provides favorable results for the indication of varieties with good industrial characteristics in the cultivation region.

For the TPH trait, in the first harvest there was small amplitude of variation, with the formation of only two groups of means. In the second harvest the amplitude was higher, being the variety CTC7 the one to present the highest average (Table 4). Fernandes et al. (2017) and Ftwi et al. (2017) also obtained great variation among the varieties in the conduction of different crop seasons for this trait when evaluating the genotypes $x$ environments interaction in sugarcane. 
Table 3 - Results of the unfolding of the varieties within harvests and harvests within varieties of the traits stalk average height (SH) in $\mathrm{cm}$, stalks average mass (SM) in $\mathrm{kg} \mathrm{colmo}^{-1}$, stalks average number per linear meter (SN) and tons of stalks per hectare (TSH), which presented significant value for the $F$ test of the interaction varieties $x$ crop seasons of 16 varieties in the crop seasons 2011/2012 and 2012/2013

\begin{tabular}{|c|c|c|c|c|c|c|c|c|}
\hline \multirow{2}{*}{$\begin{array}{c}\text { trait } \\
\text { variety }\end{array}$} & \multicolumn{2}{|c|}{$\begin{array}{l}\text { SH } \\
(\mathrm{cm})\end{array}$} & \multicolumn{2}{|c|}{$\begin{array}{l}\text { SM } \\
\text { (kg) }\end{array}$} & \multicolumn{2}{|c|}{ SN } & \multicolumn{2}{|c|}{$\begin{array}{c}\text { TSH } \\
\left(\mathrm{t} \mathrm{ha}^{-1}\right)\end{array}$} \\
\hline & $2011 / 12$ & $2012 / 13$ & $2011 / 12$ & $2012 / 13$ & $2011 / 12$ & $2012 / 13$ & 2011/12 & $2012 / 13$ \\
\hline SP891115 & $1.81 \mathrm{aB}$ & $2.16 \mathrm{bA}$ & $1.00 \mathrm{aA}$ & $0.81 \mathrm{cA}$ & $9.06 \mathrm{aB}$ & $15.38 \mathrm{aA}$ & $69.36 \mathrm{aA}$ & $44,55 \mathrm{cB}$ \\
\hline СТС9 & $1.76 \mathrm{aB}$ & $2.73 \mathrm{aA}$ & $0.79 \mathrm{aB}$ & $1.38 \mathrm{aA}$ & 7.87aB & $14.69 \mathrm{aA}$ & $57.67 \mathrm{aB}$ & 79.73aA \\
\hline RB925211 & $1.67 \mathrm{aB}$ & $2.36 \mathrm{bA}$ & $0.79 \mathrm{aA}$ & $0.84 \mathrm{cA}$ & $9.73 \mathrm{aB}$ & $14.65 \mathrm{aA}$ & $59.05 \mathrm{aA}$ & $57.03 \mathrm{bA}$ \\
\hline SP801842 & $1.63 \mathrm{aB}$ & $2.74 \mathrm{aA}$ & $0.71 \mathrm{aB}$ & $1.05 \mathrm{bA}$ & 7.87aB & 16.96aA & $43.87 \mathrm{bA}$ & $64.46 \mathrm{bA}$ \\
\hline RB925345 & $1.60 \mathrm{aB}$ & $2.55 \mathrm{aA}$ & $0.78 \mathrm{aA}$ & $0.96 \mathrm{bA}$ & $7.53 \mathrm{aB}$ & $11.47 \mathrm{bA}$ & $45.64 \mathrm{bA}$ & $49.67 \mathrm{cA}$ \\
\hline СТC2 & $1.59 \mathrm{aB}$ & $2.70 \mathrm{aA}$ & $0.57 \mathrm{bB}$ & $1.16 \mathrm{aA}$ & $8.53 \mathrm{aB}$ & $16.89 \mathrm{aA}$ & $36.46 \mathrm{bB}$ & $75.88 \mathrm{aA}$ \\
\hline RB855453 & $1.59 \mathrm{aB}$ & $2.26 \mathrm{bA}$ & $0.85 \mathrm{aA}$ & $0.92 \mathrm{bA}$ & $9.27 \mathrm{aB}$ & $18.56 \mathrm{aA}$ & $58.26 \mathrm{aA}$ & $66.98 \mathrm{bA}$ \\
\hline СТC7 & $1.51 \mathrm{bB}$ & $2.80 \mathrm{aA}$ & $0.83 \mathrm{aA}$ & $0.95 \mathrm{bA}$ & $7.93 \mathrm{aB}$ & $18.56 \mathrm{aA}$ & $50.64 \mathrm{aB}$ & $118.49 \mathrm{aA}$ \\
\hline CTC14 & $1.47 \mathrm{bB}$ & $2.48 \mathrm{aA}$ & $0.61 \mathrm{bB}$ & $1.08 \mathrm{bA}$ & $9.53 \mathrm{aB}$ & $17.25 \mathrm{aA}$ & $44.80 \mathrm{bB}$ & $83.14 \mathrm{aA}$ \\
\hline SP813250 & $1.43 \mathrm{bB}$ & $2.58 \mathrm{aA}$ & $0.58 \mathrm{bB}$ & $1.05 \mathrm{bA}$ & $9.93 \mathrm{aB}$ & $15.65 \mathrm{aA}$ & $57.64 \mathrm{aB}$ & $86.48 \mathrm{aA}$ \\
\hline CTC15 & $1.43 \mathrm{bB}$ & $2.73 a A$ & $0.79 \mathrm{aA}$ & $0.99 \mathrm{bA}$ & $8.53 \mathrm{aB}$ & $13.35 \mathrm{bA}$ & $54.18 \mathrm{aA}$ & $65.51 \mathrm{bA}$ \\
\hline CTC16 & $1.41 \mathrm{bB}$ & $2.29 \mathrm{bA}$ & $0.55 \mathrm{bB}$ & $0.80 \mathrm{cA}$ & $10.00 \mathrm{aB}$ & $16.15 \mathrm{aA}$ & $42.33 \mathrm{bA}$ & $58.12 \mathrm{bA}$ \\
\hline RB867515 & $1.39 \mathrm{bB}$ & $2.56 \mathrm{aA}$ & $0.39 \mathrm{bB}$ & $1.37 \mathrm{aA}$ & $6.20 \mathrm{aB}$ & $13.20 \mathrm{bA}$ & $29.05 b B$ & $69.52 \mathrm{bA}$ \\
\hline SP842025 & $1.32 \mathrm{bB}$ & $1.90 \mathrm{cA}$ & $0.54 \mathrm{bA}$ & $0.67 \mathrm{cA}$ & 8.87aA & $10.18 \mathrm{bA}$ & $36.85 \mathrm{bA}$ & $39.09 \mathrm{cA}$ \\
\hline СТC8 & $1.32 \mathrm{bB}$ & $2.24 \mathrm{bA}$ & $0.63 \mathrm{bA}$ & $0.88 \mathrm{cA}$ & $6.00 \mathrm{aB}$ & $12.89 \mathrm{bA}$ & 29.18bB & $65.71 \mathrm{bA}$ \\
\hline CTC1 & $1.29 \mathrm{bB}$ & $2.43 \mathrm{bA}$ & $0.59 \mathrm{bB}$ & $1.25 \mathrm{aA}$ & 7.13aB & $11.78 \mathrm{bA}$ & 33.92bB & $63.38 \mathrm{bA}$ \\
\hline mean & 1.51 & 2.47 & 0.69 & 1.01 & 8.37 & 14.85 & 46.81 & 67.98 \\
\hline
\end{tabular}

Means followed by the same lowercase letter in the column and upper case in the row belong to the same group, according to the Scott and Knott (1974) criterion at $5 \%$ probability $(p<0.05)$.

Table 4 - Results of the unfolding of the varieties within harvests and harvests within varieties of the traits total recoverable sugar (TRS), Pol\% cane (POL) and tons of Pol per hectare (TPH), which presented significant value for the F test of the interaction varieties x crop seasons of 16 varieties in the crop seasons 2011/2012 and 2012/2013

\begin{tabular}{|c|c|c|c|c|c|c|}
\hline \multirow{2}{*}{$\begin{array}{c}\text { trait } \\
\text { variety } \\
\end{array}$} & \multicolumn{2}{|c|}{ TRS } & \multicolumn{2}{|l|}{$\begin{array}{c}\text { POL } \\
(\%) \\
\end{array}$} & \multicolumn{2}{|c|}{$\begin{array}{c}\text { TPH } \\
\left(\mathrm{t} \mathrm{ha}^{-1}\right) \\
\end{array}$} \\
\hline & $2011 / 12$ & $2012 / 13$ & 2011/12 & $2012 / 13$ & 2011/12 & $2012 / 13$ \\
\hline SP891115 & $177.60 \mathrm{aA}$ & $167.80 \mathrm{aB}$ & $18.34 \mathrm{aA}$ & 17.29aB & $12.75 \mathrm{aA}$ & $7.70 \mathrm{cB}$ \\
\hline СТС9 & $174.92 \mathrm{aA}$ & $166.33 \mathrm{aA}$ & $18.05 \mathrm{aA}$ & $17.15 \mathrm{aA}$ & $10.44 \mathrm{aA}$ & $13.68 \mathrm{bA}$ \\
\hline RB925211 & 186.13aA & $175.95 \mathrm{aB}$ & $19.28 \mathrm{aA}$ & 18.17aB & $11.41 \mathrm{aA}$ & $10.33 \mathrm{cA}$ \\
\hline SP801842 & $169.08 \mathrm{bA}$ & $162.38 \mathrm{bA}$ & $17.43 \mathrm{bA}$ & $16.60 \mathrm{bA}$ & $7.62 \mathrm{bA}$ & $10.73 \mathrm{cA}$ \\
\hline RB925345 & $182.46 \mathrm{aA}$ & $175.47 \mathrm{aA}$ & $18.87 \mathrm{aA}$ & $18.11 \mathrm{aA}$ & $8.63 \mathrm{aA}$ & $9.00 \mathrm{cA}$ \\
\hline СТC2 & $161.82 \mathrm{cA}$ & $158.24 \mathrm{bA}$ & $16.63 \mathrm{cA}$ & $16.23 \mathrm{bA}$ & $6.07 \mathrm{bB}$ & $12.24 \mathrm{cA}$ \\
\hline RB855453 & $169.79 \mathrm{bA}$ & $161.71 \mathrm{bA}$ & $17.48 \mathrm{bA}$ & $16.62 \mathrm{bA}$ & 10.17aA & $11.20 \mathrm{cA}$ \\
\hline СТC7 & $181.10 \mathrm{aA}$ & $164.06 \mathrm{aB}$ & $18.72 \mathrm{aA}$ & $16.88 \mathrm{aB}$ & $9.48 \mathrm{aB}$ & $20.03 \mathrm{aA}$ \\
\hline СТC14 & $157.64 \mathrm{cA}$ & $155.11 \mathrm{bA}$ & $16.21 \mathrm{cA}$ & $15.94 \mathrm{bA}$ & $7.27 \mathrm{bB}$ & $13.25 \mathrm{bA}$ \\
\hline SP813250 & $167.39 \mathrm{bA}$ & $164.61 \mathrm{aA}$ & $17.25 \mathrm{bA}$ & $16.94 \mathrm{aA}$ & $9.97 \mathrm{aB}$ & $14.68 \mathrm{bA}$ \\
\hline CTC15 & $158.94 \mathrm{cA}$ & $154.79 \mathrm{bA}$ & $16.34 \mathrm{cA}$ & $15.90 \mathrm{bA}$ & $8.92 \mathrm{aA}$ & $10.36 \mathrm{cA}$ \\
\hline СТC16 & $169.84 \mathrm{bA}$ & $160.49 \mathrm{bA}$ & $17.52 \mathrm{bA}$ & $16.51 \mathrm{bA}$ & $7.41 \mathrm{bA}$ & $9.62 \mathrm{cA}$ \\
\hline RB867515 & $160.91 \mathrm{cA}$ & $169.62 \mathrm{aA}$ & $16.54 \mathrm{cA}$ & $17.49 \mathrm{aA}$ & $4.88 \mathrm{bB}$ & $12.23 \mathrm{cA}$ \\
\hline SP842025 & $156.83 \mathrm{cA}$ & $145.74 \mathrm{cB}$ & $16.14 \mathrm{cA}$ & $14.93 \mathrm{cB}$ & $5.93 \mathrm{bA}$ & $5.84 \mathrm{cA}$ \\
\hline СТC8 & $163.68 \mathrm{cA}$ & $156.70 \mathrm{bA}$ & $16.85 \mathrm{cA}$ & $16.11 \mathrm{bA}$ & $4.90 \mathrm{bB}$ & $10.64 \mathrm{cA}$ \\
\hline CTC1 & $161.37 \mathrm{cA}$ & $167.93 \mathrm{aA}$ & $16.62 \mathrm{cA}$ & $17.32 \mathrm{aA}$ & $5.69 \mathrm{bB}$ & $11.00 \mathrm{cA}$ \\
\hline mean & 168.72 & 162.93 & 14.40 & 16.76 & 8.22 & 11.41 \\
\hline
\end{tabular}

Means followed by the same lowercase letter in the column and upper case in the row belong to the same group, according to the Scott and Knott (1974) criterion at $5 \%$ probability $(p<0.05)$. 
The values of the repeatability coefficient were high (Table 5), except for the stalks average mass trait. According to Silva et al. (2009) the low repeatability value for the SM trait is due to the fact that it had a lot of environmental influence, causing low regularity in the repetition of the values of the variable from one crop season to another, thus, being necessary more evaluations for a better accuracy. Ferreira et al. (2005) when studying the repeatability and predictability for industrial variables in sugarcane also obtained high values for this parameter for most of the assessed traits. According to Fernandes et al. (2017), high values for the repeatability coefficient is indicative of the performance regularity of the genotypes in the different crop seasons.

Resende (2002) consider that values above $80 \%$, for the coefficient of determination parameter, are considered appropriate for the selection of genotypes. Ferreira et al. (2005) also obtained values higher than $80 \%$ for this parameter for the

Table 5 - Estimation for repeatability coefficient (r), coefficient of determination $\left(R^{2}\right)$, minimum number of measurements required to predict the true value of the phenotype with $95 \%$ confidence set $\left(n_{0}\right)$ and phenotypic correlation coefficient of the combination of two crop seasons for the traits stalk average height $(\mathrm{SH})$ in $\mathrm{cm}$, stalk average diameter (SD) in $\mathrm{mm}$, stalks average mass (SM) in $\mathrm{kg} \mathrm{colmo}^{-1}$, stalks average number per linear meter (SN), tons of stalks per hectare (TSH), total recoverable sugar (TRS), Brix\% sugarcane juice, Fiber\% cane, Pol\% cane, Purity\% sugarcane juice and tons of Pol per hectare (TPH) of 16 varieties of sugarcane assessed in the crop seasons 2011/2012 and 2012/2013

\begin{tabular}{ccccc}
\hline trait & $\mathbf{r}$ & $\mathbf{R}^{\mathbf{2}}$ & $\mathbf{n}_{0}$ & $\begin{array}{c}\text { phenotypic } \\
\text { correlation }\end{array}$ \\
\hline SH & 0,81 & 0,90 & 4 & $0,13^{\mathrm{ns}}$ \\
SD & 0,81 & 0,89 & 5 & $0,58^{* *}$ \\
SM & 0,56 & 0,72 & 15 & $-0,07^{\mathrm{ns}}$ \\
SN & 0,69 & 0,81 & 9 & $0,32^{*}$ \\
TSH & 0,70 & 0,82 & 8 & $0,14^{\mathrm{ns}}$ \\
TRS & 0,85 & 0,92 & 4 & $0,53^{* *}$ \\
Brix & 0,79 & 0,88 & 6 & $0,48^{* *}$ \\
Fiber & 0,82 & 0,90 & 5 & $0,73^{* *}$ \\
Pol & 0,85 & 0,92 & 4 & $0,53^{* *}$ \\
Purity & 0,74 & 0,85 & 7 & $0,38^{* *}$ \\
TPH & 0,72 & 0,84 & 8 & $0,18^{\text {ns }}$ \\
\hline
\end{tabular}

** - significant at $1 \%$ probability $(p<0.01)$; * significant at $5 \%$ probability $(0.01 \leq p \leq 0.05)$; ${ }^{\text {ns }}$ - not significant $(p>0.05)$ by the $F$ test. industrial traits assessed. The traits Pol and TRS were those that presented a higher value for the coefficient of determination (Table 5), denoting the good reliability of the phenotype in predicting the genotypic value for these two variables.

For the parameter, minimum number of crop seasons needed to predict the true value $\left(\mathrm{n}_{0}\right)$ of the trait TSH, this value would be of eight harvests (Table 5). A similar result for this variable was obtained by Ferreira et al. (2005), but the confidence index established by the authors was only $90 \%$. The number for the Purity trait would be of seven harvests. The highest estimate of number obtained for these traits indicates that there is no regularity in the repetition of this variable from one crop season to another, thus being necessary more evaluations. It is worth mentioning that in breeding programs and in the mills and distilleries, it is common to use up to five harvests to select the best varieties through the evaluation of the industrial traits. For the SM trait, the value of $\mathrm{n}_{0}$ would be fifteen, being a not feasible number of evaluations, due to the difficulty in conducting and harvesting sugarcane experiments.

With respect to the phenotypic correlation coefficient parameter, Jackson (2005) affirms that correlations between the same traits assessed in two periods, reflect the association of genetic and environmental nature. For this parameter, there was a significant correlation for the traits stalks average diameter, stalks number per meter, TRS, Brix, Fiber, Pol and Purity (Table 5). Nascimento Filho et al. (2009) consider the statistical significance for this parameter as indicative that the cultivars have different performance in the different harvests. However, the lack of significant correlation for the other traits probably occurred because only two harvests were considered in the present study, which tends to change with the increase of the evaluations during another crop seasons.

\section{CONCLUSIONS}

Varieties do not present a similar behavior; however, they have regularity in the performance, over time, for most agronomic and industrial characters evaluated. Phenotypic characteristics POL and TRS, denote good reliability in predicting 
the genotypic value for these variables. The high number of measurements required for the TSH, Purity and SM characters make it difficult to select potential varieties. Phenotypic correlation evaluated in two harvests is not sufficient to carry out the recommendation of varieties.

\section{ACKNOWLEDGMENT}

The authors thank the Coordination of Improvement of Higher Level Personnel (CAPES), by the research funding, to the Agronomic Institute of Campinas (IAC), for having carried out the technological analysis of this work and the Cachaça Bocaina Company, for the assignment of the experimental area and support in the accomplishment of the experiments.

\section{REFERENCES}

Brito, T.R.C.; Barbosa, T.F.; Barbosa, J.A.; Oliveira, C.R. \& Oliveira, W.F. (2013) - Desempenho de sete genótipos de cana de açúcar de quinto corte na região sul do estado do Tocantins. Revista Verde de Agroecologia e Desenvolvimento Sustentável, vol. 8, p. 78-83.

Cândido, L.S.; Perecin, D.; Landell, M.G. de A. \& Pavan, B.E. (2009) - Análise de vizinhança na avaliação de genótipos de cana-de-açúcar. Pesquisa Agropecuária Brasileira, vol. 44, n. 10, p. 1304-131. http://dx.doi. org/10.1590/S0100-204X2009001000014

Cargnelutti Filho, A.; Braga Júnior, R.L.C. \& Lúcio, A.D. (2012) - Medidas de precisão experimental e número de repetições em ensaios de genótipos de cana-de-açúcar. Pesquisa Agropecuária Brasileira, vol. 47, n. 10, p. 1413-1421.

Cavalcante, M.; Lira, M. de A.; Santos, M.V.F. dos; Pita, E.B.; Ferreira, A.; Ferreira, R.L.C. \& Tabosa, J.N. (2012) - Coeficiente de repetibilidade e parâmetros genéticos em capim-elefante. Pesquisa Agropecuária Brasileira, vol. 47, n. 4, p. 569-575.

Cruz, C.D.; Regazzi, A.J. \& Carneiro, P.C.S. (2004) - Modelos biométricos aplicados ao melhoramento genético. Viçosa: UFV, 390p.

Fernandes, O.W.B.; Silva, D.F.; Sanson, A.L.; Coutrim, M.X.; Afonso, R.J. de C.F.; Eichler, P. \& Santos, F. (2017) - Influence of Harvest Season and Maturation of Different Sugarcane (Saccharum spp.) Cultivars on the Chemical Composition of Alembic Brazilian Sugarcane Spirit. Open Access Library Journal, vol. 4, art. e3266. http://dx.doi.org/10.4236/oalib.1103266

Fernandes Júnior, A.R.; Azeredo, A.A.C. de; Oliveira, R.A. de; Bespalhok Filho, J.C.; Ido, O.T.; Daros, E. \& Brasileiro, B.P. (2017) - Agricultural performance and genetic parameters for yield-related traits of sugar - and energy cane families derived from planned crosses. Genetics and Molecular Research, vol. 16, n. 3, art. gmr16039773. http://dx.doi.org/10.4238/gmr16039773

Ferreira, A.; Barbosa, M.H.P.; Cruz, C. D.; Hoffmann, H. P.; Vieira, M.A.S.; Bassinello, A.I. \& Silva, M.F. da. (2005) - Repetibilidade e número de colheitas para seleção de clones de cana-de-açúcar. Pesquisa Agropecuária Brasileira, vol. 40, n. 8, p. 761-767. http://dx.doi.org/10.1590/\$0100-204X2005000800005

Ftwi, M.; Mekbib, F. \& Abraha, E. (2017) - Temporal and Spatial Factors Affecting the Nature of Genotype $x$ Environment Interaction in Sugarcane (Saccharum officinarum L.) under Ethiopian Agro-Climatic Conditions: An Integrated Approach. American Journal of Plant Sciences, vol. 8, n. 7, art. 77316. http://dx.doi. org/ 10.4236/ajps.2017.87119

INMET (2014) - Estações convencionais: gráficos de precipitação mensal. Instituto Nacional de Meteorologia. http://www.inmet.gov.br/portal/index.php?r=home/page\&page=rede_estacoes_conv_graf.

Jackson, P.A. (2005) - Breeding for improved sugar content in sugarcane. Field Crops Research, vol. 92, n. 2-3, p. 277-290. https://doi.org/10.1016/j.fcr.2005.01.024

Nascimento Filho, F.J.; Atroch, A.L.; Cruz, C.D. \& Carneiro, P.C.S. (2009) - Repetibilidade da produção de sementes em clones de guaraná. Pesquisa Agropecuária Brasileira, vol. 44, n. 6, p. 605-612. http://dx.doi. org/10.1590/50100-204X2009000600009 
Ramalho, M.A.P.; Ferreira, D.F. \& Oliveira, A.C. (2012) - Experimentação em genética e melhoramento de plantas. 3. ed. Lavras: UFLA, 328p.

Resende, M.D.V. (2002) - Genética biométrica e estatística no melhoramento de plantas perenes. Brasília: Embrapa Informações Tecnológicas, 975p.

Resende, M.D.V. \& Duarte, J.B. (2007) - Precisão e controle de qualidade em experimentos de avaliação de cultivares. Pesquisa Agropecuária Tropical, vol. 37, n. 3, p. 182-194.

Scott, A.J. \& Knott, M. (1974) - A cluster analysis method for grouping means in the analysis of variance. Biometrics, vol. 30, n. 3, p. 507-512.

Silva, M.A.; Gava, G.J. de C.; Caputo, M.M.; Pincelli, R.P.; Jerônimo, E.M. \& Cruz, J.C.S. (2007) - Uso de reguladores de crescimento como potencializadores do perfilhamento e da produtividade em cana-soca. Bragantia, vol. 66, n. 4, p. 545-552. http://dx.doi.org/10.1590/S0006-87052007000400003

Silva, M.A.; Jerônimo, E.M. \& Lúcio, A.D. (2008) - Perfilhamento e produtividade de cana-de-açúcar com diferentes alturas de corte e épocas de colheita. Pesquisa Agropecuária Brasileira, vol. 43, n. 8, 979-986. http:// dx.doi.org/10.1590/S0100-204X2008000800005

Silva, R.G.; Chaves M. da C.L.; Arnhold, E. \& Cruz, C.D. (2009) - Repetibilidade e correlações fenotípicas de caracteres do fruto de bacuri no Estado do Maranhão. Acta Scientiarum, Agronomy, vol. 31, n. 4, p. 587-591. http://dx.doi.org/10.4025/actasciagron.v31i4.723

Souza, P.H.; Bastos, G.Q.; Anunciação Filho, C.J. da; Dutra Filho, J. de A. \& Machado, P.R. (2012) - Avaliação de genótipos de cana-de-açúcar para início de safra na microrregião Centro de Pernambuco. Revista Ceres, vol. 59, n. 5, p. 677-683. http://dx.doi.org/10.1590/S0034-737X2012000500013 